\title{
Arbitragem Envolvendo a Administração Pública: Estado Atual no Direito Brasileiro
}

\author{
CARMEN TIBURCIO \\ Professora Associada de Direito Internacional Privado na Universidade do Estado do Rio de \\ Janeiro e da Pós-Graduação da UGF, LLM e SJD pela University of Virginia School of Law, EUA, \\ Advogada no Escritório Barroso Fontelles, Barcellos, Mendonça \& Associados.
}

\author{
Submissão: 06.09.2013 \\ Decisão Editorial: 04.10.2013
}

RESUMO: A possibilidade de entidades da Administração Pública (direta e indireta) se submeterem a procedimentos arbitrais é questão tradicionalmente polêmica no Direito brasileiro. 0 recurso à arbitragem é cada vez mais frequente e, no entanto, até bem recentemente, havia enorme insegurança a respeito do tema, que não recebia tratamento uniforme da doutrina e da jurisprudência. Atualmente, entretanto, é possível notar algum avanço acerca da matéria no Direito brasileiro. No presente trabalho, que se propõe a delinear o estado atual do tema no Direito brasileiro, com foco na jurisprudência, parte-se de uma análise sob o enfoque da arbitrabilidade subjetiva (que se refere aos participantes da relação ajustada) e objetiva (que, por sua vez, diz respeito ao objeto da relação jurídica) e, posteriormente, são examinadas decisões recentes do Superior Tribunal de Justiça. Partindo da premissa da vinculação das partes à cláusula inserida no contrato, finalmente, conclui-se ser possível a submissão de entidades da Administração Pública à arbitragem desde que haja lei autorizativa ou, na ausência desta, no caso de empresas públicas ou sociedades de economia mista que desempenhem atividade econômica, ou mesmo prestadoras de serviço público, desde que a controvérsia seja relativa à questão patrimonial.

PALAVRAS-CHAVE: Administração Pública; Arbitragem; Arbitrabilidade subjetiva e objetiva; Contratos da Administração.

ABSTRACT: The possibility of entities belonging to the Public Administration (direct and indirect) resorting to arbitration is a traditionally controversial issue in Brazilian law. The use of arbitration is increasingly common, and yet, until recently, there was huge uncertainty regarding the subject, which did not receive uniform treatment of the doctrine and jurisprudence. Currently, however, it is possible to note some progress on the matter in Brazilian law. This paper, which aims to outline the current status of the theme under Brazilian law, focusing on case law, starts with an analysis from the standpoint of subjective and objective arbitrability (the first one referring to those who are parts to the relationship and the second, to its object) and, subsequently, examines recent decisions of the Brazilian Superior Court. Based on the premise that the parts are bound to the arbitral clause inserted in the contract, this study finally concludes that the submission of government entities to arbitration is possible whenever there is a law that authorizes it or, in its absence, in the case of public companies or mixed capital companies performing economic activity, or even public service entities, provided that the controversy is limited to pecuniary rights. 
SUMÁRIO: Introdução; I - Arbitrabilidade do litígio; I.1 Arbitrabilidade subjetiva; I.2 Arbitrabilidade objetiva; II - Breve análise da jurisprudência recente do Superior Tribunal de Justiça; II.1 Recurso Especial $n^{0}$ 612.439/RS; II.2 Recurso Especial $n^{0}$ 606.345/RS; II.3 Mandado de Segurança ${ }^{0}$ 11.308/DF; II.4 Recurso Especial nº 904.813/PR; II.5 Síntese do estado atual da jurisprudência; III - Vinculação das partes à cláusula arbitral; Síntese conclusiva.

\section{INTRODUÇÃOO}

A possibilidade de entidades da Administração Pública (direta e indireta) participarem de arbitragens é questão tradicionalmente polêmica no Direito brasileiro. Até bem recentemente, havia enorme insegurança a respeito do tema, que não recebia tratamento uniforme da doutrina e da jurisprudência. Atualmente, entretanto, é possível notar algum avanço acerca da matéria no Direito brasileiro.

Nos últimos anos, algumas controvérsias em torno do tema chegaram ao Superior Tribunal de Justiça, que considerou, em dois cenários diferentes, não haver óbice à submissão à arbitragem de questões envolvendo sociedades de economia mista ou empresas públicas. Na esfera administrativa, o Tribunal de Contas da União, menos receptivo à participação da Administração Pública em arbitragens sem lei que a autorizasse começa a se alinhar com a orientação do STJ.

Esse estudo propõe-se a analisar o estado atual do Direito brasileiro acerca da controvérsia, com ênfase na posição da jurisprudência nacional a respeito. Como se verá, a evolução legislativa e jurisprudencial no Brasil, na linha da tendência atual em outros Estados ${ }^{1}$, indica que o recurso à arbitragem por parte do ente que integra a Administração Pública é prática cada vez mais frequente.

\section{I- ARBITRABILIDADE DO LITÍGIO}

A arbitragem consiste num modo extrajudiciário de heterocomposição de conflitos relativos a direitos disponíveis em que as partes, de comum acordo (convenção esta que as vincula e por meio da qual renunciam à jurisdição estatal) ${ }^{2}$, submetem a questão litigiosa a um ou mais terceiros, que constituem um tribunal arbitral. A decisão por ele exarada tem os mesmos efeitos de uma sentença judicial ${ }^{3}$.

1 DOLINGER, Jacob; TIBURCIO, Carmen. Direito internacional privado: arbitragem comercial internacional, 2003, p. 216.

2 TIBURCIO, Carmen; BARROSO, Luís Roberto. Cláusula compromissória: interpretação, efeitos e a questão intertemporal. In: FERRAZ, Rafaella; MUNIZ, Joaquim de Paiva (Coord.). Arbitragem doméstica e internacional, 2008, p. 102

3 Lei no 9.307/1996: "Art. 31. A sentença arbitral produz, entre as partes e seus sucessores, os mesmos efeitos da sentença proferida pelos órgãos do Poder Judiciário e, sendo condenatória, constitui título executivo". 
Denomina-se arbitrabilidade a viabilidade jurídica de submeter determinada controvérsia à arbitragem. O tema é relevante porque nem todas as partes podem se vincular à arbitragem e, além disso, não são todas as questões que podem ser apreciadas em juízos arbitrais. Dizer que o litígio não é arbitrável significa que não pode ser solucionado por tribunal arbitral, de modo que a arbitrabilidade é uma condição de validade da convenção de arbitragem e, consequentemente, da competência dos árbitros ${ }^{4}$.

O termo arbitrabilidade relaciona-se, portanto, à possibilidade de determinada pessoa ou litígio submeter-se à arbitragem. Tal característica comporta exame sob dois ângulos distintos e complementares: (i) arbitrabilidade subjetiva (ou ratione personae) - a possibilidade de as partes envolvidas se sujeitarem ao juízo arbitral; e (ii) arbitrabilidade objetiva (ou ratione materiae) - a viabilidade de a questão controvertida ser submetida à arbitragem ${ }^{5}$. Assim, para determinar a arbitrabilidade do litígio, é necessário apreciá-lo por essas duas perspectivas. É o que se passa a fazer.

\section{I.1 Arbitrabilidade SUBjetiva}

Em geral, a arbitrabilidade subjetiva de um litígio depende apenas da capacidade das partes envolvidas. É o que dispõe o art. $1^{\circ}$ da Lei de Arbitragem (Lei no 9.307/1996), que, em sua primeira parte, somente admite a participação em arbitragens de pessoas capazes de contratar ${ }^{6-7}$. A ratio da norma é autoevidente: a opção pelo juízo arbitral não se presume, nem pode ser imposta, devendo decorrer da vontade expressa das partes, formalizada por escrito ${ }^{8}$. Aqueles que não tenham adquirido a plena capacidade civil - que, no Direito brasileiro, é determinada pela lei do lugar em que tenham domicílio, no caso

4 DOLINGER, Jacob; TIBURCIO, Carmen. Direito internacional privado: arbitragem comercial internacional, 2003, p. 213.

5 FOUCHARD; GAILLARD; GOLDMAN. On international commercial arbitration (Edited by Emmanuel Galliard, John Savage), 1999, p. 312; LEMES, Selma. Arbitragem na Administração Pública, 2007. p. 116 e 124; DOLINGER, Jacob; TIBURCIO, Carmen. Direito internacional privado: arbitragem comercial internacional, 2003. p. 213; ARAGÃO, Alexandre Santos de. Arbitragem e regulação. Revista de Arbitragem e Mediação 27:70, 2010; LEMES, Selma Maria Ferreira. Arbitragem na concessão de serviços públicos - Arbitrabilidade objetiva. Confidencialidade ou publicidade processual? Revista de Direito Bancário e Mercado de Capitais 21:387, 2003.

6 Lei $n^{\circ}$ 9.307/1996: "Art. $1^{\circ}$ As pessoas capazes de contratar poderão valer-se da arbitragem para dirimir litígios relativos a direitos patrimoniais disponíveis". Na mesma linha, dispõe o Código Civil, em seu art. 851: "É admitido compromisso, judicial ou extrajudicial, para resolver litígios entre pessoas que podem contratar".

$7 \quad$ LEMES, Selma. Arbitragem na Administração Pública, 2007, p. 116.

8 Lei $n^{\circ} 9.307 / 1996$, arts. $3^{\circ}, 4^{\circ}$ e $9^{\circ}$ : "Art. $3^{\circ}$ As partes interessadas podem submeter a solução de seus litígios ao juízo arbitral mediante convenção de arbitragem, assim entendida a cláusula compromissória e o compromisso arbitral. Art. $4^{\circ} \mathrm{A}$ cláusula compromissória é a convenção através da qual as partes em um contrato comprometem-se a submeter à arbitragem os litígios que possam vir a surgir, relativamente a tal contrato. $\S 1^{\circ} \mathrm{A}$ cláusula compromissória deve ser estipulada por escrito, podendo estar inserta no próprio contrato ou em documento apartado que a ele se refira. [...] Art. $9^{\circ} 0$ compromisso arbitral é a convenção através da qual as partes submetem um litígio à arbitragem de uma ou mais pessoas, podendo ser judicial ou extrajudicial. $\S 1^{\circ} \mathrm{O}$ compromisso arbitral judicial celebrar-se-á por termo nos autos, perante o juízo ou tribunal, onde tem curso a demanda. $\S 2^{\circ} \mathrm{O}$ compromisso arbitral extrajudicial será celebrado por escrito particular, assinado por duas testemunhas, ou por instrumento público". 
de pessoas naturais (LINDB, art. $\left.7^{\circ}\right)^{9}$, ou, em se tratando de pessoas jurídicas estrangeiras, pela legislação do local em que se constituírem (LINDB, art. 11) ${ }^{10}$ -, por não poderem validamente vincular-se pela manifestação de sua vontade, estão impedidos de submeterem-se à arbitragem.

Portanto, como regra geral, tratando-se de pessoas jurídicas brasileiras (vale dizer: constituídas de acordo com as leis brasileiras e possuindo sede no Brasil), plenamente capazes, são aptas, em tese, a submeter litígios a procedimento arbitral. Nada obstante, a presença de entidade da Administração Pública brasileira torna o ponto mais complexo, suscitando controvérsias ${ }^{11}$.

Em princípio, a mesma competência que autoriza esses entes a firmar contratos para criar, modificar, ceder ou extinguir seus direitos e obrigações Ihes permitiria também firmar uma convenção de arbitragem. Porém, a presença do interesse público na gestão e/ou nas funções dessas pessoas jurídicas demanda um aprofundamento adicional. O principal óbice, aqui, é o princípio da legalidade (CF/1988, art. 37, caput), segundo o qual, na sua acepção tradicional, a Administração Pública não pode agir, senão com autorização legal.

A doutrina divide-se em três correntes nessa matéria ${ }^{12}$. De um lado, há autores para quem qualquer entidade da Administração poderia firmar convenções arbitrais por força do art. 54, caput, da Lei $\mathrm{n}^{0}$ 8.666/1993 ${ }^{13}$, que determina a aplicação supletiva dos princípios da teoria geral dos contratos e das disposições de direito privado aos contratos por ela regidos ${ }^{14}$.

Uma segunda corrente sustenta, por sua vez, que a autorização presente em inúmeras leis pontuais relacionadas à Administração Pública - é o caso da Lei do Petróleo (Lei no 9.478/1997, art. 43, X), da Lei de Concessões (Lei no 8.987/1995, art. 23-A) e da Lei das Parcerias Público-Privadas (Lei no 11.079, art. 11, III) - constituiria um sistema do qual se poderia extrair autorização genérica para a adoção da arbitragem em qualquer circunstância. Após o reconhecimento da constitucionalidade da Lei de Arbitragem, aliás, diversas leis, decretos e resoluções normativas da Agência Nacional de Energia Elétrica (Aneel)

9 Lei de Introdução às Normas do Direito Brasileiro (Decreto-Lei no 4.657/1942): "Art. $7^{\circ} \mathrm{A}$ lei do país em que domiciliada a pessoa determina as regras sobre o começo e o fim da personalidade, o nome, a capacidade $e$ os direitos de família".

10 Lei de Introdução às Normas do Direito Brasileiro (Decreto-Lei no 4.657/1942): "Art. 11. As organizações destinadas a fins de interesse coletivo, como as sociedades e as fundações, obedecem à lei do Estado em que se constituírem" (TIBURCIO, Carmen. Disciplina legal da pessoa jurídica à luz do direito internacional brasileiro. Revista Semestral de Direito Empresarial 8:175, 2011).

11 DOLINGER, Jacob; TIBURCIO, Carmen. Op. cit., p. 389.

12 DOLINGER, Jacob; TIBURCIO, Carmen. Op. cit., p. 426 e ss.; BARROSO, Luís Roberto. Sociedade de economia mista prestadora de serviço público, cláusula arbitral inserida em contrato administrativo sem prévia autorização legal. Invalidade. In: Temas de direito constitucional, t. II, 2003. p. 620.

13 Lei no 8.666/1993: "Art. 54. Os contratos administrativos de que trata esta lei regulam-se pelas suas cláusulas e pelos preceitos de direito público, aplicando-se-lhes, supletivamente, os princípios da teoria geral dos contratos e as disposições de direito privado".

14 Essa é a opinião de DALLARI, Adilson Abreu. Arbitragem na concessão de serviço público. Revista de Informação Legislativa do Senado Federal 128:65, 1995. 
previram a arbitragem como meio de solução de controvérsias entre os diversos atores do setor, referentes a distintas relações contratuais ${ }^{15}$.

No caso específico das sociedades de economia mista e empresas públicas exploradoras de atividade econômica, uma terceira corrente afirma que tais entidades seriam plenamente aptas a se submeter à arbitragem, por força do art. 173, § 1ํㅡㄹ da Constituição ${ }^{16-17}$. Mais recentemente, essa última orientação passou também a admitir a participação em arbitragens de sociedades de economia mista e empresas públicas prestadoras de serviço público, desde que o objeto da controvérsia seja de conteúdo econômico ${ }^{18}$. O ponto será retomado a seguir.

A jurisprudência tem se mostrado bastante favorável à participação de entidades públicas em arbitragens. Mesmo antes das decisões mais recentes sobre o tema, o Supremo Tribunal Federal, em célebre julgamento de 1973, relativo ao caso Lage ${ }^{19}$, considerou válida disposição legal que autorizava a submissão da Administração à arbitragem, afirmando, para tanto, que rejeitar as convenções arbitrais firmadas pela Fazenda Pública seria restringir indevidamente a autonomia contratual do Estado ${ }^{20}$. Por outro lado, no extinto Tribunal Federal de Recursos, a prévia autorização legal foi considerada um requisito essencial para a arbitragem envolvendo o Estado ${ }^{21}$.

Atualmente, o Superior Tribunal de Justiça tem adotado uma tendência favor arbitratis, na linha da formulação mais recente da terceira corrente apresentada acima. Valendo-se do art. 173, § 1ํ, da Constituição, o STJ admite a

15 FERRAZ, Rafaella. Possibilidades e limites à aplicação da arbitragem no setor elétrico. In: FERRAZ, Rafaella; MUNIZ, Joaquim de Paiva (Coord.). Arbitragem doméstica e internacional, 2008, p. 331 e ss.

$16 \mathrm{CF} / 1988$ : "Art. 173. [...] $\S 1^{\circ} \mathrm{A}$ lei estabelecerá o estatuto jurídico da empresa pública, da sociedade de economia mista e de suas subsidiárias que explorem atividade econômica de produção ou comercialização de bens ou de prestação de serviços, dispondo sobre: [...] II - a sujeição ao regime jurídico próprio das empresas privadas, inclusive quanto aos direitos e obrigações civis, comerciais, trabalhistas e tributários; III - licitação e contratação de obras, serviços, compras e alienações, observados os princípios da administração pública; [...]".

17 Essa linha é seguida, por exemplo, por Luís Roberto Barroso, que, embora tenha sugerido inicialmente outra orientação (Sociedade de economia mista prestadora de serviço público, cláusula arbitral inserida em contrato administrativo sem prévia autorização legal. Invalidade. In: Temas de direito constitucional, t. II, 2003), esclareceu posteriormente que adota posicionamento diverso, segundo o qual a exigência de prévia autorização legislativa não se aplicaria às empresas estatais que desempenhem atividade econômica - v. BARROSO, Luís Roberto. Agências reguladoras: constituição, transformações do Estado e legitimidade democrática. In: BINENBOJM, Gustavo (Coord.). Agências reguladoras e democracia, 2006. p. 75-6 (nota n 54). 0 autor expressou claramente sua opinião nesse sentido em TIBURCIO, Carmen; BARROSO, Luís Roberto. Direito constitucional internacional, 2013. p. 570-1.

18 TIBURCIO, Carmen; BARROSO, Luís Roberto. Op. cit., p. 570-1.

19 O "caso Lage" envolveu a incorporação à União de bens e direitos das empresas das Organizações Lage e, mais especificamente, a indenização devida aos Espólios de Henrique Lage e Renaud Lage por essa incorporação. Nos termos do Decreto-Lei no 9.521/1946, o valor seria definido por arbitragem.

20 STF, Al 52.181/GB, Rel. Min. Bilac Pinto, DJ 15.02.1974. Esse precedente foi citado, e.g., em STF, RE 253.885/MG, Rela Min. Ellen Gracie, DJ 21.06.2002.

21 TFR, AC 137.279/DF, Rel. Min. Bueno de Souza, DJ 26.06.1989. Na doutrina, aparentemente no mesmo sentido, v. MELLO, Celso Antônio Bandeira de. Sociedade de economia mista prestadora de serviço público - Submissão à arbitragem - Contrato com empresa estrangeira e submissão ao direito público brasileiro. In: Pareceres de direito administrativo, 2011. p. 270. 
participação em arbitragens não só de sociedades de economia mista, mas também de empresas públicas, inclusive prestadoras de serviços públicos ${ }^{22}$, sendo dispensável autorização legislativa para tanto ${ }^{23}$.

Mesmo o Tribunal de Contas da União, que mostrava certa resistência à arbitragem na Administração Pública ${ }^{24-25}$ - supostamente, o interesse público estaria melhor protegido se as controvérsias fossem submetidas ao Judiciário ${ }^{26}$ -, tem admitido, mais recentemente, a celebração de convenções de arbitragem pelas empresas estatais não só em contratos relativos à sua atividade-fim² ${ }^{27}$, como também nos casos em que a utilização da arbitragem restar justificada técnica e economicamente.

22 Mesmo empresas estatais prestadoras de serviços públicos podem se submeter à arbitragem, desde que se trate de questão patrimonial e disponível, como o equilíbrio econômico-financeiro do contrato - v. STJ, REsp 904.813/PR, Rela Min. Nancy Andrighi, DJ 28.02.2012: "9. A controvérsia estabelecida entre as partes - manutenção do equilíbrio econômico financeiro do contrato - é de caráter eminentemente patrimonial e disponível, tanto assim que as partes poderiam tê-la solucionado diretamente, sem intervenção tanto da jurisdição estatal, como do juízo arbitral. 10. A submissão da controvérsia ao juízo arbitral foi um ato voluntário da concessionária. Nesse contexto, sua atitude posterior, visando à impugnação desse ato, beira às raias da má-fé, além de ser prejudicial ao próprio interesse público de ver resolvido o litígio de maneira mais célere. 11. Firmado o compromisso, é o Tribunal arbitral que deve solucionar a controvérsia".

23 STJ, REsp 612.439/RS, Rel. Min. João Otávio Noronha, DJ 14.09.2006: "São válidos e eficazes os contratos firmados pelas sociedades de economia mista exploradoras de atividade econômica de produção ou comercialização de bens ou de prestação de serviços (CF, art. 173, § $1^{\circ}$ ) que estipulem cláusula compromissória submetendo à arbitragem eventuais litígios decorrentes do ajuste". STJ, REsp 606.345/RS, Rel. Min. João Otávio Noronha, DJ 14.09.2006; STJ, AgRg-MS 11.308/DF, Rel. Min. Luiz Fux, DJ 14.08.2006: "Nestes termos, as sociedades de economia mista encontram-se em situação paritária em relação às empresas privadas nas suas atividades comerciais, consoante leitura do art. $173, \S 1^{\circ}$, II, da Constituição Federal, evidenciando-se a inocorrência de quaisquer restrições quanto à possibilidade de celebrarem convenções de arbitragem para solução de conflitos de interesses, uma vez legitimadas para tal as suas congêneres"; STJ, REsp 904.813/PR, Re| ${ }^{a}$ Min. Nancy Andrighi, DJe 28.02.2012: "[...] não existe óbice legal na estipulação da arbitragem pelo Poder Público, notadamente pelas sociedades de economia mista, admitindo como válidas as cláusulas compromissórias previstas em editais convocatórios de licitação e contratos [...]".

24 TCU, Acórdão n 1.099/06 - Plenário, Rel. Min. Augusto Nardes, DOU 10.07.2006. Para outras referências, v. TIBURCIO, Carmen. A arbitragem envolvendo a Administração Pública. Revista de Direito do Estado 6:341, 2007.

25 Segundo Dennys Zimmermann (Alguns aspectos sobre a arbitragem nos contratos administrativos à luz dos princípios da eficiência e do acesso à justiça: por uma nova concepção do que seja interesse público. Revista de Arbitragem e Mediação 12:69, 2007): "No âmbito do Tribunal de Contas da União, verificou-se as mais acirradas objeções à utilização da via arbitral de solução de conflitos em contratos administrativos. Afirmava a eg. Corte de Controle que, em sendo indisponível o interesse público, não poderiam os entes administrativos a que impende velar pela sua escorreita gestão - renunciar ao exercício da jurisdição estatal em benefício da adoção de um mecanismo dissuasório alternativo".

26 Cabe mencionar, entretanto, que o próprio arcabouço legal brasileiro afastaria o temor de que submeter a Administração a tal instituto colocaria em risco a defesa de seus interesses ou de que os mesmo estariam melhor protegidos se submetidos ao Judiciário. V. LEMES, Selma. Arbitragem na Administração Pública, 2007. p. 78; ZIMMERMANN, Dennys. Alguns aspectos sobre a arbitragem nos contratos administrativos à luz dos princípios da eficiência e do acesso à justiça: por uma nova concepção do que seja interesse público. Revista de Arbitragem e Mediação 12:69, 2007: "A associação entre a adoção da via arbitral de solução de conflitos e a tutela do interesse privado (ou, melhor dizendo, do interesse dos parceiros privados da Administração) - em contraposição à, de outra banda, associação entre a jurisdição estatal e a proteção do interesse público 'subjacente ao contrato administrativo' - revela-se fruto de uma visão limitada e unidimensional do fenômeno arbitral, que não o leva em consideração sob os seus diferentes prismas e ângulos de visada".

27 LEMES, Selma. Op. cit., p. 136 e 137. 
O cenário começou a ser alterado em decisão de 2009 acerca de controvérsia que envolvia a Petrobras ${ }^{28}$. No caso, o TCU entendeu que, tratando-se de sociedades de economia mista, em que as contratações podem versar sobre direitos disponíveis ou indisponíveis, seriam disponíveis somente aqueles relativos a sua atividade-fim, e que seria razoável permitir a utilização de juízo arbitral na resolução de questões ou disputas técnicas que os envolvessem, tendo em vista tratar-se de assunto especializado.

Agora, o Tribunal avançou ainda mais na sua flexibilização acerca da matéria. Decisão do TCU de agosto de 2013 admitiu a possibilidade de empresas públicas e sociedades de economia mista se submeterem à arbitragem ainda que sem autorização legal neste sentido ${ }^{29}$. Ao decidir o caso, que também envolvia a Petrobras, o Tribunal afastou-se ainda mais de sua tradicional relutância em aceitar a arbitragem nesse contexto e passou a admitir a cláusula compromissória sem previsão legal, desde que preenchidas as seguintes condições: (i) compatibilidade com a prática do mercado no setor e (ii) existência

28 V. TCU, Acórdão n 2.094/2009 - Plenário, Rel. Min. José Jorge, DOU 11.09.2009, em que se reconheceu a validade das cláusulas compromissórias celebradas pela Petrobras, desde que restritas à "resolução de eventuais litígios a assuntos relacionados à sua área-fim e disputas eminentemente técnicas oriundas da execução dos aludidos contratos". O ponto ficou ainda mais claro na manifestação de órgão técnico (Secob) do Tribunal que, reproduzida no relatório do acórdão, embasou a decisão proferida. Após citar a jurisprudência do STJ (REsp 612.439/RS), a Secob afirmou: "Em razão da natureza jurídica dos contratos celebrados por sociedades de economia mista, as contratações podem versar sobre direitos disponíveis ou indisponíveis. Entende-se que serão disponíveis somente aqueles relativos à área-fim da Petrobras ou suas subsidiárias, de cunho estritamente comercial, as quais a Constituição coloca em posição de igualdade com o regime jurídico das empresas privadas, nos termos do art. 173". Como a exploração de energia é atividade-fim da ELN, está atendida a exigência do Tribunal.

29 TCU, Acórdão n 2.145/2013 - Plenário, Rel. Min. Benjamin Zymler, DOU 22.08.2013: "Relatório de levantamento de auditoria. Determinações. Pedido de reexame. Conhecimento. Obrigatoriedade de celebração de contratos em língua portuguesa para a produção de efeitos no País. Cláusula arbitral, possibilidade desde que justificada técnica e economicamente. Contratação no modelo turn key. Considerações. Provimento parcial. Ciência à recorrente. [...] como regra geral, o compromisso arbitral não é cabível nos contratos administrativos, sendo as exceções objeto de específica disposição legal. 31. Há de se ver, contudo, a peculiar situação das sociedades de economia mista exploradoras de atividade econômica, as quais, consoante o disposto no inciso II do art. 173 da Constituição Federal, estão sujeitas ao regime jurídico próprio das empresas privadas. [...] em que pese a ausência de disposição legal específica [...], o Superior Tribunal de Justiça entendeu que a possibilidade de utilização do instituto da arbitragem pelas sociedades de economia mista exploradoras de atividade econômica ganha respaldo diretamente do texto constitucional. 35. Essa linha de entendimento, consistente no reconhecimento de que alguns procedimentos dessas empresas exploradoras de atividade econômica podem ser justificados diretamente do texto constitucional, não é nova nesta Corte de Contas. Nesse sentido, o decidido no bojo de consulta mediante o Acórdão n 1390/2004 - Plenário, quando se concluiu que a essas estatais cabe a incidência mitigada das normas de licitação nas hipóteses de contratações relacionadas às atividades-fim. 36. Entretanto, há que se considerar também que essas entidades são integrantes da Administração Pública [...]. 37. Desta feita, em que pese a jurisprudência do STJ não ter estabelecido limites para a utilização da cláusula arbitral - até porque a solução dos casos concretos não o exigiu -, entende-se que a arbitragem somente deve ser utilizada em situações peculiares devidamente justificadas e de modo a se seguir a comprovada prática de mercado. [...] determinadas questões técnicas e econômicas, por sua complexidade, demandam conhecimento especializado para sua solução. Trata-se de situações em que a instituição de cláusula arbitral pode propiciar maior segurança jurídica às partes contratantes e contribuir para a regular execução do objeto contratual. 40. Esse entendimento, destaco, independe de se tratar a contratação de atividade-fim ou não da empresa. Isto posto, entendo que a decisão impugnada deve ser alterada de forma que a utilização de cláusula arbitral não seja restrita à atividade fim da empresa, devendo entretanto ser justificada técnica e economicamente e ser de acordo com a prática de mercado" (grifos nossos). 
de justificativa sob o viés técnico e econômico. Interessante observar que o Tribunal deixou claro que a controvérsia a ser submetida à arbitragem não precisa estar vinculada à atividade-fim do ente público. A permissão decorreu da aplicação do art. 173, § 1ํㅡㄹ da Constituição Federal, envolvendo, portanto, empresas públicas e sociedades de economia mista no desempenho de atividade econômica.

Em síntese, o entendimento majoritário na matéria aponta no seguinte sentido. Como regra geral, para que sejam válidas, as convenções arbitrais firmadas por entes da Administração dependem de prévia autorização legislativa (princípio da legalidade). A primeira exceção à regra envolve empresas públicas e sociedades de economia mista exploradoras de atividade econômica, às quais se aplica o art. 173, § 1ํㅡㄹ da Constituição ${ }^{30}$. Em segundo lugar, é possível que empresa estatal prestadora de serviço público submeta determinado litígio à arbitragem, desde que a controvérsia não envolva direito indisponível nem interesse público primário.

Note-se que a doutrina mais recente tem observado que o princípio da legalidade sofreu importantes mutações. A Administração Pública, na verdade, encontra-se vinculada à observância da juridicidade, conceito que vai além da mera observância às leis ${ }^{31}$. Nesse contexto, a obediência ao princípio da legalidade é mais facilmente demonstrada. De fato, há quem sustente que, sendo capazes na esfera civil, as entidades da Administração já poderiam considerar-se autorizadas a optar pela solução arbitral de controvérsias pelo próprio art. $1^{\circ}$ da Lei da Arbitragem, que não distingue entidades públicas e privadas ${ }^{32}$. Não constitui violação a qualquer preceito dispor da arbitragem para solucionar desentendimentos envolvendo a Administração, desde que em contratos que

30 Essa é a orientação atual de Luís Roberto Barroso (Agências reguladoras: constituição, transformações do Estado e legitimidade democrática. In: BINENBOJM, Gustavo (Coord.). Agências reguladoras e democracia, 2006, p. 75-6, nota $n^{\circ} 54$ ): "Em parecer acerca de situação específica - envolvendo sociedade de economia mista prestadora de serviço público -, fiz uma afirmação mais abrangente do que aquela que de fato corresponde ao meu pensamento na matéria. Em caso de serviços públicos dotados de essencialidade, em relação aos quais possa haver implicações para a soberania nacional, é razoável a exigência de lei autorizando a solução de conflitos por arbitragem internacional. Tal lógica não se estende aos casos de empresas públicas e sociedades de economia mista exploradoras de atividade econômica. Isso porque o art. 173 da Constituição determina que tais entidades tenham, tanto quanto possível, regime jurídico equiparado ao das empresas privadas. [...] A regra, portanto, é a sujeição ao regime próprio das empresas privadas, as quais têm se valido cada vez mais da previsão de arbitragem em seus contratos, até mesmo como elemento de facilitação negocial e obtenção de financiamentos mais favoráveis. Essa foi, aliás, a ótica que prevaleceu na recente Lei n 10.079/1904, que disciplinou as chamadas parcerias público-privadas (PPPs)". Também se manifesta nesse sentido em TIBURCIO, Carmen; BARROSO, Luís Roberto. Direito constitucional internacional, 2013, p. $570-1$.

31 BINENBOJM, Gustavo. Uma teoria do direito administrativo, 2008, p. 143: "A ideia de juridicidade administrativa traduz-se, assim, na vinculação da Administração Pública ao ordenamento jurídico como um todo, a partir do sistema de princípios e regras delineado na Constituição. A juridicidade administrativa poderá, portanto: i) decorrer diretamente da normativa constitucional; ii) assumir a feição de uma vinculação estrita à lei (formal ou material); ou iii) abrir-se à disciplina regulamentar (presidencial ou setorial), autônoma ou de execução, conforme os espaços normativos (e sua peculiar disciplina) estabelecidos constitucionalmente".

32 Nesse sentido, v. LEMES, Selma. Arbitragem na Administração Pública, 2007, p. 115. 
se refiram a questões negociais ${ }^{33}$. O ponto será retomado no tópico referente à arbitrabilidade objetiva.

De fato, inexiste razão que justifique a submissão necessária da Administração à via judicial. Nada impede que, diante da pretensão de um contratante, o Poder Público reconheça espontaneamente um erro que tenha cometido e o corrija - muito ao contrário, o que se espera justamente é que o faça ${ }^{34}$. Igualmente, a entidade da Administração pode submeter a questão à arbitragem ${ }^{35}$, quando essa for a solução mais benéfica: de maneira mais imediata, a arbitragem oferece ao conflito resposta mais breve e formulada por especialistas no tema; em perspectiva mais ampla, permite atrair melhores contratantes e propostas, em áreas em que a submissão à arbitragem seja praxe no mercado em questão. Em resumo, sua adoção representa diminuição no custo de transação e economia de recursos públicos ${ }^{36}$.

Ainda nessa linha, não seria possível reduzir a liberdade contratual da Administração Pública sem qualquer justificativa razoável. Negar seu acesso à arbitragem, consoante os ditames da Lei no 9.307/1996, reduziria injustificadamente o âmbito de aplicação do comando legal e, ao mesmo tempo, constituiria inconstitucionalidade, pela afronta aos princípios da razoabilidade, da proporcionalidade, da eficiência, da razoabilidade e da economicidade. A arbitragem promove todos os princípios mencionados: sua utilização em contratos administrativos conduz à otimização, eficiência, economicidade e moralidade, pois a Administração estará honrando o avençado de acordo com a boa-fé e lealdade contratuais, conferindo-se ao direito administrativo a necessária flexibilidade e consensualidade ${ }^{37-38-39}$. Demonstrada a arbitrabilidade subjetiva do litígio, resta examinar se o litígio em si pode ser submetido à arbitragem.

33 LEMES, Selma. Op. cit., p. 107.

34 TÁCITO, Caio. Arbitragem nos litígios administrativos. Revista de Direito Administrativo 210:114, 1997.

35 V. Arnoldo Wald e André Serrão (Aspectos constitucionais e administrativos da arbitragem nas concessões. Revista de Direito Administrativo 16:11, 2008): "Se, durante muito tempo, tivemos dúvidas e polêmicas em relação à sujeição do Poder Público à arbitragem, podemos afirmar que, nos dois últimos anos, firmou-se definitivamente, nos planos legislativo, jurisprudencial e doutrinário, a convicção sobre a validade da cláusula compromissória nos contratos de direito administrativo, abrangendo não somente as sociedades de economia mista e as agências reguladoras, mas também o próprio Estado".

36 LEMES, Selma. Op. cit., p. 35.

37 LEMES, Selma. Op. cit., p. 99 e 104 e ss.

38 V. Arnoldo Wald e André Serrão (Aspectos constitucionais e administrativos da arbitragem nas concessões. Revista de Direito Administrativo 16:11, 2008): "[...] também o acesso à segurança jurídica, à celeridade e à especialização técnica de um tribunal arbitral podem constituir um interesse público primário, cuja indisponibilidade, ao contrário de proibir a sua utilização, estaria a exigir que a Administração Pública viesse a valer-se da arbitragem".

39 V. Dennys Zimmermann (Alguns aspectos sobre a arbitragem nos contratos administrativos à luz dos princípios da eficiência e do acesso à justiça: por uma nova concepção do que seja interesse público. Revista de Arbitragem e Mediação 12:69, 2007): "Com efeito, longe de contradizer o interesse público, situações fatuais existem - e não são poucas - em que a previsão contratual da arbitragem se constitui no único viés possíve - e, por que não dizer, eficiente (e novamente o adjetivo não está sendo utilizado de maneira desarrazoada, como se verá adiante) - de se satisfazê-lo, em razão das garantias de celeridade, efetividade e imparcialidade que somente a consagração consensual desta via proporciona aos parceiros privados da Administração". 


\section{I.2 ARBITRABILIDADE OBJETIVA}

A arbitrabilidade objetiva está prevista na parte final do art. 1ํa a qual apenas admite a arbitragem "para dirimir litígios relativos a direitos patrimoniais disponíveis" ${ }^{40}$. Isso significa que as partes só podem optar pelo juízo arbitral quando se cuidar de direitos sobre os quais tenham pleno poder de disposição afinal, se podem até cedê-los ou renunciar a eles, podem também submetê-los à decisão de um árbitro. Embora a regra, no direito privado, seja a disponibilidade dos direitos e, com isso, a arbitrabilidade das $\operatorname{lides}^{41}$, não é isso que se verifica no direito público. Na seara administrativa, em que vigora a indisponibilidade do interesse público, a questão apresenta nuances e contornos especiais: por não serem titulares dos direitos em jogo, os administradores públicos não têm poder de disposição direta sobre eles. Dessa forma, quando se trata de arbitragem envolvendo o Estado ou suas subdivisões, faz-se necessário analisar não só a capacidade do ente de direito público firmar compromisso arbitral, mas também a matéria que será submetida a esse procedimento ${ }^{42}$.

A adequada compreensão do ponto exige cautela. Um frequente equívoco na matéria é a confusão entre o interesse público propriamente dito - também chamado de interesse público primário - e o interesse da Administração Pública - ou interesse público secundário ${ }^{43-44}$. O primeiro deles diz respeito aos próprios fins do Estado, i.e., aos objetivos que justificam a existência da sociedade política, em particular a promoção do princípio da dignidade da pessoa humana pela tutela e efetivação dos direitos fundamentais ${ }^{45}$. Já o segundo, também chamado de interesse público derivado ou instrumental, existe para

40 LEMES, Selma. Op. cit., p. 116 e 124.

41 Há, no entanto, exceções - v. Código Civil: "Art. 852. É vedado compromisso para solução de questões de estado, de direito pessoal de família e de outras que não tenham caráter estritamente patrimonial".

42 DOLINGER, Jacob; TIBURCIO, Carmen. Direito internacional privado: arbitragem comercial internacional, 2003, p. 389.

43 A diferença remonta a Renato Alessi (Principi di diritto amministrativo, v. I, p. 226-7, 1974): "Questi interessi pubblici, collettive, dei quali l'amministrazione deve curare il soddisfacimento, non sono, si noti bene, semplicemente l'interesse dell'Amministrazione intesa come apparato organizzativo autonomo, sibbene quello che è stato chiamato l'interesse collettivo primario, formato dal complesso degli interessi individuali prevalenti in una determinata organizzazione giuridica della collettività, mentre l'interesse dell'aparato, se può esser concepito un interesse dell'aparato unitariamente considerato, sarebbe semplicemente uno deg/i interessi secondari che si fanno sentire in seno alla collettività, e che possono essere realizzati soltanto in caso di coincidenza, e nei limiti di sifatta coincidenza, con l'interesse collettivo primario". Sua aplicação ao Direito brasileiro é pacífica. V., por todos, MELLO, Celso Antônio Bandeira de. Curso de direito administrativo, 2003, p. 56-8; JUSTEN FILHO, Marçal. Curso de direito administrativo, 2005, p. 37 e ss.

44 Essa distinção também tem repercussões processuais. O Ministério Público, que, nos termos da lei, deve intervir em todos os processos "em que há interesse público evidenciado pela natureza da lide ou qualidade da parte" (CPC, art. 82, III), está dispensado de fazê-lo em demandas relativas a interesses meramente secundários.

45 Segundo Marçal Justen Filho (Curso de direito administrativo, 2005, p. 43-4): "Um interesse deixa de ser privado quando sua satisfação não possa ser objeto de alguma transigência. Recolocando o problema em outros termos, um interesse é público por ser indisponível, e não o inverso. Por isso, é incorreto afirmar que algum interesse, por ser público, é indisponível. [...] Portanto, a indisponibilidade não é consequência da natureza pública do interesse - é justamente o contrário. 0 interesse é reconhecido como público porque é indisponível, porque não pode ser colocado em risco, porque sua natureza exige que seja realizado. [...] Tudo evidencia que a questão não reside num 'interesse público', de conteúdo obscuro. 0 ponto fundamental é a 
operacionalizar o primário, correspondendo aos interesses instrumentais ou acessórios do Poder Público, com características patrimoniais, como o aumento na arrecadação de recursos e a redução das despesas ${ }^{46}$.

Enquanto o interesse público primário é verdadeiramente indisponível por sua natureza, o interesse secundário pode ser - e frequentemente é - objeto de disposição por parte do Estado ${ }^{47}$. Muitas vezes, a própria satisfação do interesse primário recomendará que o Poder Público efetue mais gastos ou abra mão de determinadas pretensões patrimoniais - é o que ocorre, e.g., quando se regulariza a posse de áreas indevidamente ocupadas para promover o direito fundamental à moradia (CF/1988, art. 6oํ) ${ }^{48}$.

A mesma lógica da disposição de direitos aplica-se também à validade da convenção arbitral. A Administração pode pactuar cláusulas compromissórias ou celebrar compromissos arbitrais quando se tratar de direitos sobre os quais possa dispor ${ }^{49}$. Quando o Estado atua fora de sua condição de entidade pública

questão ética, a configuração de um direito fundamental. Ou seja, o núcleo do direito administrativo não reside no interesse público, mas nos direitos fundamentais".

46 LEMES, Selma. Op. cit., p. 131.

47 Segundo Eros Roberto Grau (Arbitragem e contrato administrativo. Revista Trimestral de Direito Público 32:20, 2000): "[...] é evidente que, quando se afirma que a arbitragem se preste a dirimir litígios relativos a direitos patrimoniais disponíveis, isto não significa não possa a Administração socorrer-se dessa via visando ao mesmo fim. Pois não há qualquer correlação entre a disponibilidade ou indisponibilidade de direitos patrimoniais e a disponibilidade ou indisponibilidade do interesse público". Nesse sentido, v. STJ, REsp 1.153.076/GO, Rel. Min. Luiz Fux, DJ 29.03.2010: “1. A exegese do disposto no art. 82, III, do CPC impõe a distinção jusfilosófica entre o interesse público primário e o interesse da administração, cognominado ‘interesse público secundário' [...]. 2. O Estado, quando atestada a sua responsabilidade, revela-se tendente ao adimplemento da correspectiva indenização, coloca-se na posição de atendimento ao 'interesse público'. Ao revés, quando visa a evadir-se de sua responsabilidade no afã de minimizar os seus prejuízos patrimoniais, persegue nítido interesse secundário, subjetivamente pertinente ao aparelho estatal em subtrair-se de despesas, engendrando locupletamento à custa do dano alheio. 3. Deveras, é assente na doutrina e na jurisprudência que indisponível é o interesse público, e não o interesse da administração. Nessa última hipótese, não é necessária a atuação do Parquet no mister de custos legis, máxime porque a entidade pública empreende a sua defesa por meio de corpo próprio de profissionais da advocacia da União. Precedentes jurisprudenciais que se reforçam, na medida em que a atuação do Ministério Público não é exigível em várias ações movidas contra a Administração, como, v.g., sói ocorrer, com a ação de desapropriação prevista no Decreto-Lei no 3.365/1941 (Lei de Desapropriação). 4. In genere, as ações que visam ao ressarcimento pecuniário contêm interesses disponíveis das partes, não necessitando, portanto, de um órgão a fiscalizar a boa aplicação das leis em prol da defesa da sociedade" (grifos nossos).

48 Segundo Eros Roberto Grau (Arbitragem e contrato administrativo. Revista Trimestral de Direito Público 32:20, 2000): "É certo que inúmeras vezes [a Administração] deve dispor de direitos patrimoniais, sem que com isso esteja a dispor do interesse público, porque a realização deste último é alcançada mediante a disposição daquele".

49 Segundo Diogo de Figueiredo Moreira Neto (Mutações do direito administrativo, 2007, p. 284): "Toda a questão do cabimento da arbitragem na órbita interna se reduz, assim, à definição do campo contratual em que a Administração negocia e estatui como qualquer particular, excluídas, portanto, quaisquer cláusulas em que seja prevista a satisfação de um interesse finalístico da sociedade, cometido ao Estado, esse sim, indisponível". Segundo Caio Tácito (Arbitragem nos litígios administrativos. Revista de Direito Administrativo 210:115, 1997): "Se, indubitavelmente, em certos casos, o princípio da indisponibilidade do interesse público repele o compromisso arbitral, não há por que obstar o benefício da transação quando a natureza da obrigação de conteúdo mercantil, a ser cumprida pelo órgão público, possibilita que ao acordo de vontade, fruto do vínculo bilateral, possa igualmente suceder o procedimento amigável como dirimente de eventual discrepância no entendimento da latitude da obrigação do administrador". Segundo Alexandre Santos de Aragão (Arbitragem e regulação. Revista de Arbitragem e Mediação 27:70, 2010). STJ, REsp 612.439/RS, Rel. Min. João Otávio de Noronha, DJ 14.09.2006: "[...] quando os contratos celebrados pela empresa 
e pratica ato de natureza privada, situado na ordem privada, equipara-se ao particular, pois a relação ajustada rege-se não pelo direito público, mas pelo privado. Se a Administração fosse substituída por um particular em qualquer dos polos da relação ajustada, nada se alteraria ${ }^{50}$.

Nesse ponto, vale fazer breve menção aos motivos - equivocados - geralmente apontados como justificativas da vedação de utilização da arbitragem em contratos administrativos ${ }^{51}$. Primeiramente, faz-se uma analogia entre compromisso e transação, de modo que a capacidade para firmar compromisso decorreria não da capacidade para contratar, mas para transigir. Como o direito de se submeter à arbitragem suporia o de transigir, não podendo a Fazenda transacionar, não poderia igualmente firmar compromisso. Esse argumento parte de bases equivocadas, entretanto. Tais figuras não se confundem nem na natureza, nem nos efeitos. Pode firmar cláusula compromissória quem pode contratar, e o Estado pode. Quando a Administração submete-se à arbitragem, não está transigindo com o interesse público, mas deslocando o litígio do Judiciário para os árbitros.

O segundo argumento baseia-se numa analogia entre o poder de firmar compromisso com o mandato e a necessidade da outorga de poderes especiais de mandatário para firmar compromisso. Ocorre que o gestor público não atua como mandatário do Estado, mas como agente público, de modo que o argumento simplesmente não se sustenta.

Ademais, trata-se de matéria patrimonial - não há que se confundir com as questões legais e constitucionais relativas à soberania ou à economia nacional. Nessas situações, o interesse público (primário) muitas vezes corresponderá, na verdade, à busca por uma solução rápida e tecnicamente mais consisten$t^{52}$, o que, longe de impedir, poderá antes recomendar a celebração de uma convenção arbitral ${ }^{53}$.

estatal versem sobre atividade econômica em sentido estrito [...], os direitos e as obrigações deles decorrentes serão transacionáveis, disponíveis e, portanto, sujeitos à arbitragem [...]" e "[...] estando o objeto do contrato de serviço público prestado pela entidade estatal estritamente vinculado à atividade econômica desenvolvida pela empresa estatal [...], inexiste óbice a que seja pactuada a respectiva cláusula compromissória". STJ, REsp 606.345/RS, Rel. Min. João Otávio de Noronha, DJ 08.08.2007.

50 MAGALHÃES, José Carlos de. Do Estado na arbitragem privada, 1988, p. 104.

51 LEMES, Selma. Arbitragem na Administração Pública, 2007, p. 70 e ss.

52 Segundo Eros Roberto Grau (Arbitragem e contrato administrativo. Revista Trimestral de Direito Público 32:20, 2000): "Sempre que puder contratar, o que importa disponibilidade de direitos patrimoniais, poderá a Administração, sem que isso importe disposição do interesse público, convencionar cláusulas de arbitragem".

53 V. DALLARI, Adilson Abreu. Arbitragem na concessão de serviço público. Revista de Informação Legislativa do Senado Federal 128:66, 1995: "Cabe ressaltar que, ao optar pela arbitragem, o contratante público não está transigindo com o interesse público nem abrindo mão de instrumentos de defesa de interesses públicos. Está, sim, escolhendo uma forma mais expedita ou um meio mais hábil para a defesa do interesse público. Assim como o juiz, no procedimento judicial, deve ser imparcial, também o árbitro deve decidir com imparcialidade. 0 interesse público não se confunde com o mero interesse da Administração ou da Fazenda Pública; 0 interesse público está na correta aplicação da lei e se confunde com a realização concreta da justiça. Inúmeras vezes, para defender o interesse público, é preciso decidir contra a Administração Pública"; LEMES, Selma Maria Ferreira. Arbitragem na concessão de serviços públicos - Arbitrabilidade objetiva. Confidencialidade ou publicidade processual? Revista de Direito Bancário e Mercado de Capitais 21:387, 2003: "[...] não 


\section{II - BREVE ANÁLISE DA JURISPRUDÊNCIA RECENTE DO SUPERIOR TRIBUNAL DE JUSTIÇA}

Nos últimos 7 anos, algumas controvérsias em torno do tema foram levadas ao STJ, que, reiteradamente, decidiu na linha aqui apresentada: não há óbice à submissão à arbitragem de questões envolvendo sociedades de economia mista ou empresas públicas em duas situações: i) na hipótese de os entes públicos desempenharem corriqueiramente atividade econômica, ou, ii) tratando-se de prestador de serviço público, quando o cerne da discussão seja de cunho econômico. A seguir são apresentados, resumidamente, os quatro casos decididos pelo Superior Tribunal de Justiça, em especial naquilo em que guardam semelhança com a presente consulta.

\section{II.1 ReCURSO ESPECIAL N ${ }^{0} 612.439 /$ RS $^{54}$}

O recurso especial foi interposto contra julgado do TJRS em que se decidiu que a existência de compromisso arbitral não teria condão de afastar a apreciação do litígio pelo Poder Judiciário.

A Companhia Estadual de Energia Elétrica (CEEE), sociedade de economia mista, alegava que a AES Uruguaiana Empreendimentos Ltda. havia descumprido injustificadamente contrato firmado entre elas. A AES sustentou haver no contrato cláusula compromissória, requerendo a extinção do processo, o que foi rejeitado pela Magistrada de primeira instância por entender que a CEEE, sociedade de economia mista prestadora de serviço público essencial, consistente na produção e distribuição de energia elétrica, não poderia abrir mão do devido processo legal sem a autorização do legislativo estadual, e que a via arbitral seria mera faculdade, a ser utilizada pelos litigantes somente de comum acordo. A decisão foi mantida em $2^{\circ}$ grau, com base no argumento de que, nos termos do art. 5ํㅡ XXXV, da CF, é livre o acesso ao Poder Judiciário.

No recurso especial, a AES defendeu a obrigatoriedade da cláusula compromissória para a solução de conflitos surgidos na execução do contrato e alegou violação aos arts. 8º e 20 da Lei no 9.307/1996, já que os autos não foram remetidos ao juízo arbitral, competente para julgar, em primeiro lugar, qualquer questão relativa à validade e eficácia da convenção arbitral, nos termos do princípio da competência-competência.

Em seu voto, o Ministro João Otávio de Noronha (relator) teceu algumas considerações a respeito da natureza jurídica da cláusula compromissória e dos efeitos decorrentes de sua inserção no contrato para decidir que, ao estipu-

obstante se submeter às regras do direito público, estas não impedem, ao contrário, autorizam a utilização da arbitragem para solucionar os diferendos oriundos do contrato e que digam respeito aos interesses públicos derivados com repercussões patrimoniais, que nos contratos de concessão encontram guarida nas cláusulas financeiras e econômicas (repercussões técnicas e econômicas)".

54 STJ, REsp 612.439/RS, Rel. Min. João Otávio de Noronha, DJ 14.09.2006; STJ, EDcl-REsp 612.439/RS, Rel. Min. João Otávio de Noronha, DJ 06.06.2007; STJ, DJ 21.08.2007. 
lar no contrato cláusula compromissória, estará definitivamente imposta como obrigatória a via extrajudicial para solução dos litígios envolvendo o ajuste, não podendo o juízo arbitral ser afastado unilateralmente, e que não se configuraria ofensa à Constituição.

O relator passou a analisar, então, a possibilidade de uma sociedade de economia mista celebrar contrato de compra e venda com cláusula compromissória e concluiu:

Submetida a sociedade de economia mista ao regime jurídico de direito privado e celebrando contratos situados nesta seara jurídica, não parece haver dúvida quanto à validade de cláusula compromissória por ela convencionada, sendo despicienda a necessidade de autorização do Poder Legislativo a referendar tal procedimento.

Em outras palavras, pode-se afirmar que, quando os contratos celebrados pela empresa estatal versem sobre atividade econômica em sentido estrito - isto é, serviços públicos de natureza industrial ou atividade econômica de produção ou comercialização de bens, suscetíveis de produzir renda e lucro -, os direitos e as obrigações deles decorrentes serão transacionáveis, disponíveis e, portanto, sujeitos à arbitragem. Ressalte-se que a própria lei que dispõe acerca da arbitragem - art. 1ํㅡㄹ Lei $n^{\circ}$ 9.307/1996 - estatui que "as pessoas capazes de contratar poderão valer-se da arbitragem para dirimir litígios relativos a direitos patrimoniais disponíveis".

Por outro lado, quando as atividades desenvolvidas pela empresa estatal decorram do poder de império da Administração Pública e, consequentemente, sua consecução esteja diretamente relacionada ao interesse público primário, estarão envolvidos direitos indisponíveis e, portanto, não sujeitos à arbitragem. (grifos nossos)

Destacou, então, o caráter comercial do objeto do litígio, concluindo pela inexistência de óbice ao recurso à arbitragem, nos seguintes termos:

Estando o objeto do contrato de serviço público prestado pela entidade estatal estritamente vinculado à atividade econômica desenvolvida pela empresa estatal - no caso, venda de energia elétrica -, inexiste óbice a que seja pactuada a respectiva cláusula compromissória. (grifos nossos)

\section{II.2 ReCURSO ESPECIAL N ${ }^{0} 606.345 /$ RS $^{55}$}

Assim como o anterior, o REsp foi interposto contra julgado em que se decidiu que a existência de compromisso arbitral não teria condão de afastar a apreciação de qualquer questão pelo Poder Judiciário. Novamente, a AES

55 STJ, REsp 606.345/RS, Rel. Min. João Otávio de Noronha, DJ 08.08.2007; STJ, RE-EDcl-REsp 606.345/RS, DJ 01.02.2008; STJ, EDcl-RE-EDcl-REsp 606.345/RS, DJe 14.03.2008. 
Uruguaiana Empreendimentos Ltda. defendeu a obrigatoriedade da cláusula compromissória para a solução de conflitos surgidos na execução do contrato.

O relator, Ministro João Otávio de Noronha, reconheceu identidade de questões com o já mencionado REsp 612.349/RS, reportando-se ao voto que proferiu na ocasião, entendendo não haver nada mais a acrescentar. Em síntese: i) ao estipular no contrato cláusula compromissória, estará definitivamente imposta como obrigatória a via extrajudicial para solução dos litígios envolvendo o ajuste e não haveria, nessas hipóteses, ofensa ao preceito do art. 5o, XXXV, da CF; e ii) submetida a sociedade de economia mista ao regime jurídico de direito privado e celebrando contratos situados nesta seara jurídica, não parece haver dúvida quanto à validade de cláusula compromissória por ela convencionada.

\section{II.3 Mandado de Segurança N0 $11.308 /$ DF $^{56}$}

Tratava-se de mandado de segurança com pedido de liminar impetrado pela empresa TMC - Terminal Multimodal de Coroa Grande - SPE - S/A contra ato do Ministro de Estado da Ciência e Tecnologia, que, por meio de portaria, anuiu com a rescisão de contrato de arrendamento procedida pela empresa Nuclebrás Equipamentos Pesados S/A - Nuclep, sociedade de economia mista regida pela Lei das Sociedades Anônimas. Aduziu incompetência da autoridade coatora para rescindir tal contrato e violação de cláusulas contratuais, entre as quais a que estipulava que as partes recorreriam ao processo de arbitragem antes de ingressar em juízo.

A liminar foi deferida e a União interpôs recurso sustentando a impossibilidade de sociedade de economia mista estabelecer cláusula arbitral em contrato administrativo de arrendamento, pois a arbitragem violaria interesse público, o qual foi desprovido. Opôs, então, embargos declaratórios reiterando os mesmo argumentos e apontando que, por prestar serviços públicos, a Nuclep deveria submeter-se a regime jurídico de direito público e que, portanto, por tratar-se de um instituto privado, a arbitragem não poderia ser aplicada. Tais embargos restaram rejeitados, e, instado a se manifestar, o Parquet Federal opinou:

In casu, por se tratar tão somente de contrato administrativo versando cláusulas pelas quais a Administração está submetida a uma contraprestação financeira, indubitável o cabimento da arbitragem. Não faria sentido ampliar o conceito de indisponibilidade à obrigação de pagar vinculada à obra ou serviço executado a benefício auferido pela Administração em virtude da prestação regular do outro contratante. A arbitragem se revela, portanto, como o mecanismo adequado para a solução da presente controvérsia, haja vista tratar-se de relação contratual de natureza disponível, conforme dispõe o art. $1^{\text {o }}$ da Lei no 9.307/1996: "As pessoas

56 STJ, MS 11.308/DF, Rel. Min. Luiz Fux, DJe 15.05.2008; STJ, AgRG-MS 11.308/DF, Rel. Min. Luiz Fux, DJ 14.08.2006; STJ, EDcl-AgRg-MS 11.308/DF, Rel. Min. Luiz Fux, DJ 30.01.2006. 
capazes de contratar poderão valer-se da arbitragem para dirimir litígios relativos a direitos patrimoniais disponíveis". (grifos nossos)

O Relator Ministro Luiz Fux procedeu à análise dos limites jurídicos da possibilidade de o Poder Público, por meio de sociedade de economia mista, estipular cláusula compromissória em contratos administrativos com particulares. Citou doutrina que sustenta a legalidade da submissão do Poder Público à arbitragem, mas asseverou que não é qualquer direito público que poderá ser sindicado na via arbitral, mas somente aqueles "disponíveis", de natureza contratual ou privada:

A sociedade de economia mista, quando engendra vínculo de natureza disponível, encartado no mesmo cláusula compromissória de submissão do litígio ao Juízo Arbitral, não pode pretender exercer poderes de supremacia contratual previsto na Lei no ${ }^{\text {8 }}$.666/1993.

Não haveria, então, qualquer restrição quanto à possibilidade de sociedades de economia mista celebrarem convenções de arbitragem para solução de conflitos de interesses. Assim, inadmitir tal estipulação em um contrato administrativo, firmado entre partes de natureza comercial, seria restringir em hipótese na qual a lei não o fez.

No caso, a arbitragem seria o mecanismo adequado para solução da controvérsia, visto tratar-se de relação contratual de natureza disponível. Assim, estaria afastada a jurisdição estatal, pois, uma vez convencionada pelas partes cláusula arbitral, o árbitro vira juiz de fato e de direito da causa. A União interpôs agravo regimental contra essa decisão, mas o relator decidiu que a agravante não trouxera nenhum argumento capaz de infirmá-la.

\section{II.4 RecurSo EspeCIAL No 904.813/PR 57}

Tratava-se de recurso interposto pela Companhia Paranaense de Gás Natural - Compagas contra acórdão do TJPR, requerendo declaração de nulidade de compromisso arbitral em face do Consórcio Carioca Passarelli, alegando, entre outros, indisponibilidade do interesse público. A ação foi julgada improcedente, sob o argumento de que a controvérsia levada ao juízo arbitral referia-se exclusivamente à recomposição da equação econômico-financeira, não se tratando de direito indisponível, de modo que nada obstaria a solução do conflito por meio do juízo arbitral.

A Compagas interpôs apelação cujo provimento foi negado pelo TJPR em ementa que consignou que "a atividade desenvolvida pela autora, ou seja, a exploração dos serviços de gás canalizado, não constitui prestação de servi-

57 STJ, REsp 904.813/PR, Rel ${ }^{a}$ Min. Nancy Andrighi, DJe 28.02.2012; STJ, AgRg-REsp 904.813/PR, Rel Min. Nancy Andrighi, DJe 18.10.2012; STJ, EREsp 904.813/PR, Rel. Min. João Otávio de Noronha, DJe 04.03.2013. 
ço público, mas atividade que se compreende no regime jurídico próprio das empresas privadas", entendendo ser admissível nos contratos administrativos a solução dos conflitos por meio de compromisso arbitral.

O recurso interposto pela Compagas apontou dissídio jurisprudencial e violação de dispositivos legais, aduzindo novamente a invalidade/ineficácia do compromisso arbitral sem objeto determinado e ausência de previsão no certame licitatório acerca da solução de conflitos por meio de arbitragem. Tal recurso foi inadmitido pelo TJPR, tendo sido interposto agravo de instrumento da decisão denegatória, que foi provido para determinar a subida do especial.

O acórdão recorrido concluía, tendo em conta a disponibilidade dos interesses envolvidos e o regime jurídico de direito privado aplicável à hipótese, ser admissível a arbitragem. A relatora, Ministra Nancy Andrighi, apontou que

tanto a doutrina como a jurisprudência já sinalizaram no sentido de que não existe óbice legal na estipulação da arbitragem pelo Poder Público, notadamente pelas sociedades de economia mista, admitindo como válidas as cláusulas compromissórias previstas em editais convocatórios de licitação e contratos.

A peculiaridade no presente caso estaria no fato de que, no contrato celebrado, não fora estabelecida cláusula compromissória: o compromisso arbitral foi firmado posteriormente. Todavia, o fato de não haver previsão da arbitragem no edital de licitação ou no contrato celebrado entre as partes não o invalida, não havendo de se pensar em violação ao princípio da vinculação das partes ao edital de licitação. E tampouco a previsão do juízo arbitral vulnera o conteúdo ou as regras do certame. Ademais, segundo o STJ, sequer a existência de cláusula de eleição de foro no contrato constituiria óbice à arbitragem:

Não é incompatível com o juízo arbitral. Entre as várias razões apontadas pela doutrina, pode-se mencionar: a necessidade de atuação do Poder Judiciário para a concessão de medidas de urgência; para a execução da sentença arbitral; para a própria instituição da arbitragem quando uma das partes não a aceita de forma amigável. [...] Especificamente, no âmbito do Poder Público, há ainda a questão da impossibilidade de instituição do juízo arbitral para dirimir determinadas controvérsias que envolvem direitos indisponíveis, sendo necessária, portanto, a atuação da jurisdição estatal, cuja competência será fixada pela cláusula de foro prevista obrigatoriamente nos contratos administrativos. Esse, contudo, não é o caso dos autos [...], a controvérsia estabelecida entre as partes é de caráter eminentemente patrimonial e disponível, tanto assim que as partes poderiam tê-la solucionado diretamente [...].

A relatora observou também que a submissão a compromisso arbitral que a recorrente impugnou foi ato voluntário da Administração, de modo que tal atitude (de impugnar seu próprio ato) beira às raias da má-fé, além de ser evidentemente prejudicial ao próprio interesse público de ver resolvido o litígio de maneira mais célere. 


\section{II.5 SínteSE do ESTAdO atUaL dA JURISPRUDÊNCIA}

No primeiro julgado, REsp 612.439/RS, a condição de sociedade de economia mista prestadora de serviço público não foi considerada óbice para que a Companhia Estadual de Energia Elétrica (CEEE) inserisse cláusula compromissória em contrato de compra e venda por ela celebrado. Tratava-se de direitos disponíveis, os quais podem ser submetidos à arbitragem. A conclusão foi reproduzida no REsp 606.345/RS, no qual, ao reconhecer identidade de questões com a demanda anterior, o relator (também o Ministro João Otávio de Noronha) reproduziu como razão de decidir os termos de seu voto no acórdão anterior.

No terceiro caso aqui apresentado, o MS 11.308/DF, a controvérsia envolvia a Nuclebrás Equipamentos Pesados S/A - Nuclep (sociedade de economia mista que tem por objeto projetar, desenvolver, fabricar e comercializar componentes pesados relativos a usinas nucleares e a outros projetos), num contrato administrativo de arrendamento. Além de o próprio Parquet Federal haver opinado no sentido de que a arbitragem seria mecanismo adequado para a resolução da questão, visto tratar-se de relação contratual de natureza disponível, o relator, Ministro Luiz Fux, também não viu restrição quanto à possibilidade de sociedades de economia mista celebrarem convenções arbitrais e acrescentou que impedir tal estipulação em um contrato administrativo, firmado entre partes de natureza comercial, significaria impor restrição não prevista em lei.

Por fim, no REsp 904.813/PR, interposto pela Companhia Paranaense de Gás Natural - Compagas, sociedade de economia mista exploradora de serviços de gás canalizado (serviço público, conforme o art. 25, § 2º, da Constituição Federal $\left.{ }^{58}\right)$, havia ainda a peculiaridade de não estar prevista nem no certame licitatório nem no contrato a solução de conflitos por meio de arbitragem: o compromisso arbitral foi firmado posteriormente. Entendeu-se que esse fato, entretanto, não o invalidaria, tampouco consistiria violação ao princípio da vinculação das partes ao edital ou às regras do certame, visto serem disponíveis os interesses envolvidos e, portanto, ser aplicável regime jurídico de direito privado.

À luz dos precedentes expostos, é possível perceber que o Superior Tribunal de Justiça chancelou a orientação favorável à possibilidade de arbitragem envolvendo a Administração Pública em dois diferentes cenários: i) quando se tratar de sociedade de economia mista ou empresa pública exploradora de atividade econômica; ou ii) na hipótese de empresa estatal prestadora de serviço público, desde que a controvérsia a ser submetida a procedimento arbitral gire em torno de direitos patrimoniais, ou seja, que a questão tenha cunho econômico.

58 "Art. 25. Os Estados organizam-se e regem-se pelas Constituições e leis que adotarem, observados os princípios desta Constituição. $\S 2^{\circ}$ Cabe aos Estados explorar diretamente, ou mediante concessão, os serviços locais de gás canalizado, na forma da lei, vedada a edição de medida provisória para a sua regulamentação." 


\section{III - VINCULAÇ̃̃O DAS PARTES À CLÁUSULA ARBITRAL}

Por fim, é relevante tecer breves comentários quanto às cláusulas arbitrais firmadas em contratos administrativos. Aplica-se à arbitragem, no Direito brasileiro, o princípio da competência-competência (Kompetenz-Kompetenz), segundo o qual a validade da cláusula arbitral - autônoma em relação ao contrato em que se insere -, bem como a extensão e a profundidade da cognição que ela permite, pode e deve ser apreciada pelos próprios árbitros escolhidos pelas partes $^{59}$. Mais do que isso, existe uma verdadeira reserva de primeira palavra do tribunal arbitral nessa matéria: a intervenção judicial quanto ao ponto só é permitida depois de instaurada a arbitragem e proferida a sentença arbitral, em sede de ação anulatória nos termos da Lei da Arbitragem, art. 33.

No caso em estudo, a submissão à arbitragem decorre também dos princípios da boa-fé e da obrigatoriedade dos contratos (pacta sunt servanda) - e esse é o segundo ponto a ser destacado. Com efeito, seria desleal a postura da parte que, despida de qualquer causa de hipossuficiência ${ }^{60}$, celebrasse uma convenção arbitral apenas para depois ignorá-la e buscar o Judiciário. Admitir a judicialização prematura desse ponto seria premiar a torpeza e a deslealdade, o que é obviamente inadmissível. Não é outra a orientação do Superior Tribunal de Justiça:

Direito civil e processual civil. Arbitragem. Acordo optando pela arbitragem homologado em juízo. Pretensão anulatória. Competência do juízo arbitral. Inadmissibilidade da judicialização prematura. 1. Nos termos do art. $8^{\circ}$, parágrafo único, da Lei de Arbitragem, a alegação de nulidade da cláusula arbitral instituída em acordo judicial homologado e, bem assim, do contrato que a contém, deve ser submetida, em primeiro lugar, à decisão do próprio árbitro, inadmissível a judicialização prematura pela via oblíqua do retorno ao Juízo. 2. Mesmo no caso de o acordo de vontades no qual estabelecida a cláusula arbitral no caso de haver sido homologado judicialmente, não se admite prematura ação anulatória diretamente perante o Poder Judiciário, devendo ser preservada a solução arbitral, sob pena de se abrir caminho para a frustração do instrumento alternativo de

59 Lei da Arbitragem: "Art. $8^{\circ}$ A cláusula compromissória é autônoma em relação ao contrato em que estiver inserta, de tal sorte que a nulidade deste não implica, necessariamente, a nulidade da cláusula compromissória. Parágrafo único. Caberá ao árbitro decidir de ofício, ou por provocação das partes, as questões acerca da existência, validade e eficácia da convenção de arbitragem e do contrato que contenha a cláusula compromissória". Na jurisprudência, v. STJ, AgRg-MS 11.308/DF, Rel. Min. Luiz Fux, DJ 14.08.2006: "Outrossim, vige na jurisdição privada [i.e., na arbitragem], tal como sucede naquela pública, o princípio do Kompetenz-Kompetenz, que estabelece ser o próprio juiz quem decide a respeito de sua competência". STJ, RCL 9.030/SP, Rela Min. Nancy Andrighi (decisão monocrática), DJ 01.08.2012: "A teor do disposto nos arts. $8^{\circ}$, parágrafo único, e 20, da Lei no 9.307/1996, questões atinentes à existência, validade e eficácia da cláusula compromissória deverão ser apreciadas pelo árbitro. Trata-se da Kompetenz-Kompetenz (competência-competência), um dos princípios basilares da arbitragem, que confere ao árbitro o poder de decidir sobre a sua própria competência, sendo condenável qualquer tentativa, das partes ou do juiz estatal, no sentido de alterar essa realidade".

60 Não havendo no caso qualquer sombra de vulnerabilidade ou hipossuficiência, sequer é necessário cogitar de situações em que o trabalhador ou o consumidor - para ficar com os exemplos mais tradicionais - firma uma convenção arbitral. Essas situações, portanto, não estão abrangidas pelo presente estudo. 
solução da controvérsia. 3. Extingue-se, sem julgamento do mérito (CPC, art. 267, VII), ação que visa anular acordo de solução de controvérsias via arbitragem, preservando-se a jurisdição arbitral consensual para o julgamento das controvérsias entre as partes, ante a opção das partes pela forma alternativa de jurisdição. 4. Recurso especial provido e sentença que julgou extinto o processo judicial restabelecida. ${ }^{61}$ (grifos nossos)

Assim, em linha de princípio, só há uma forma de a arbitragem prevista em convenção não se realizar: aquela em que o autor formula judicialmente a sua pretensão e o réu deixa de suscitar - como deve - o pressuposto processual negativo previsto no art. 267, VII, do $\mathrm{CPC}^{62}$. Em todos os outros casos, a arbitragem deve ser instaurada normalmente: se, intentada a ação judicial, o réu suscitar a preliminar referida, deve o Juízo extinguir o processo sem exame de mérito ${ }^{63}$; se uma das partes se recusar à instituição da arbitragem, a outra pode valer-se da ação prevista no art. $7^{0}$ da Lei da Arbitragem para instituí-la compulsoriamente, mesmo que a cláusula firmada pelas partes seja considerada "vazia", ou seja, que não contenha todos os elementos necessários para a instituição da arbitragem, como ocorre no contrato objeto deste estudo. O réu descontente, portanto, só dispõe de uma via para manifestar sua alegação de invalidade da convenção arbitral: sua primeira manifestação no procedimento arbitral ${ }^{64}$. Embora os árbitros possam declarar a nulidade da convenção de ofício, se o requerido não apresentar impugnação quanto ao ponto, presumir-se-á sua aquiescência à arbitragem, o que, por preclusão lógica ${ }^{65}$, o impedirá de questionar a validade da convenção arbitral posteriormente - inclusive por meio de ação anulatória66.

61 STJ, REsp 1.302.900/MG, Rel. Min. Sidnei Beneti, DJ 16.10.2012.

62 CPC: "Art. 267. Extingue-se o processo, sem resolução de mérito: [...] VII - pela convenção de arbitragem; [...]".

63 Não se admite a extinção de ofício nessa hipótese (CPC, art. 301, § $4^{\circ}$ ).

64 Lei n 9.307/1996: "Art. 20. A parte que pretender arguir questões relativas à competência, suspeição ou impedimento do árbitro ou dos árbitros, bem como nulidade, invalidade ou ineficácia da convenção de arbitragem, deverá fazê-lo na primeira oportunidade que tiver de se manifestar, após a instituição da arbitragem. § $1^{\circ}$ Acolhida a arguição de suspeição ou impedimento, será o árbitro substituído nos termos do art. 16 desta lei, reconhecida a incompetência do árbitro ou do tribunal arbitral, bem como a nulidade, invalidade ou ineficácia da convenção de arbitragem, serão as partes remetidas ao órgão do Poder Judiciário competente para julgar a causa. $\S 2^{\circ}$ Não sendo acolhida a arguição, terá normal prosseguimento a arbitragem, sem prejuízo de vir a ser examinada a decisão pelo órgão do Poder Judiciário competente, quando da eventual propositura da demanda de que trata o art. 33 desta lei".

65 Dá-se a preclusão lógica quando uma parte pratica um ato incompatível com uma determinada faculdade processual que, por isso, se perde. (CÂMARA, Alexandre Freitas. Lições de direito processual civil, 1999, p. 406)

66 Quando da homologação de sentenças arbitrais estrangeiras, a posição tradicional do STJ é exatamente assim - v. STJ, SEC 856/GB, Rel. Min. Carlos Alberto Menezes Direito, DJ 27.06.2005: "Tem-se como satisfeito o requisito da aceitação da convenção de arbitragem quando a parte requerida, de acordo com a prova dos autos, manifestou defesa no juízo arbitral, sem impugnar em nenhum momento a existência da cláusula compromissória". E também nas seguintes decisões: STJ, REsp 612.439/RS, Rel. Min. João Otávio de Noronha, DJ 14.09.2006; STJ, REsp 606.345/RS, Rel. Min. João Otávio de Noronha, DJ 08.08.2007. 
Uma vez firmada cláusula compromissória (ou compromisso arbitral), os contratantes ficam a ela vinculados, devendo cumprir a obrigação de instituição de arbitragem ${ }^{67}$. A Administração (assim como qualquer outro contratante) deve honrar o avençado na cláusula arbitral do contrato firmado, não podendo invocar tal condição para inquinar de invalidade a arbitragem e submeter a questão ao Judiciário ${ }^{68}$.

\section{SÍNTESE CONCLUSIVA}

Como visto, a capacidade de o Estado submeter-se a procedimento arbitral deve ser examinada não apenas em face dos participantes da relação ajustada (arbitrabilidade subjetiva), mas também do objeto dessa relação jurídica (arbitrabilidade objetiva). Examinando-se ambos os enfoques, conclui-se ser possível a submissão de entidades da Administração Pública à arbitragem orientação recentemente também adotada pela jurisprudência, desde que haja lei autorizativa ou, na ausência desta, no caso de empresas públicas ou sociedades de economia mista que desempenhem atividade econômica, ou mesmo prestadoras de serviço público, desde que a controvérsia seja relativa a questão patrimonial.

67 TIBURCIO, Carmen; BARROSO, Luís Roberto. Cláusula compromissória: interpretação, efeitos e a questão intertemporal. In: FERRAZ, Rafaella; MUNIZ, Joaquim de Paiva (Coord.). Arbitragem doméstica e internacional, 2008, p. 107.

68 LEMES, Selma. Arbitragem na Administração Pública, 2007, p. 185. V. também STJ, MS 11.308/DF, Rel. Min. Luiz Fux, DJe 15.05.2008: "[...] a sociedade de economia mista, quando engendra vínculo de natureza disponível, encartado no mesmo cláusula compromissória de submissão do litígio ao Juízo Arbitral, não pode pretender exercer poderes de supremacia contratual previsto na Lei n 8.666/1993". 